\title{
THE INFLUENCE OF THE MANAGEMENT (MOTIVATIONAL) FUNCTION ON THE IMPLEMENTATION OF NEW CONCEPTS OF MANAGEMENT IN BUSINESS PRACTICES
}

\author{
Wojciech ŻEBROWSKI \\ Warsaw University of Technology, Faculty of Management, Warsaw, Poland \\ e-mail:w.zebrowski@wz.pw.edu.pl \\ Zdzisław PIĄTKOWSKI*, Anna KUŁAKOWSKA** \\ University of Ecology and Management, Warsaw, Poland \\ *e-mail: ulises@onet.eu \\ **e-mail: ann1960@wp.pl \\ Artur PIĄTKOWSKI \\ University of Warsaw, Faculty of Management, Warsaw, Poland \\ e-mail: artur.piatkowski@yahoo.com
}

\begin{abstract}
The aim of the article is to discuss the results of a study about the influence of one of the management functions, the motivational function, on the implementation of new concepts in enterprises. The research includes such issues as the use of new concepts in accomplishing objectives as well as factors, which make companies work more effectively once these concepts have been introduced. This presentation and the detailed analysis of the empirical research conducted gives insight into how new concepts of management are used in practice.
\end{abstract}

Keywords: motivation, motivational factors, motivational function and tools, management concepts, management methods, effective functioning of businesses.

\section{$1 \quad$ Introduction}

In the subject literature, it is underlined that motivation is a set of many single motives, which influence humans to various degrees [2, p. 167]. It is a force that drives people to take action and directs human pursuit of goals. The basis of these motives can be found in the needs that determine certain human behaviors meant to fulfill those needs, as well as the aims individuals either set for themselves or are externally imposed upon them. The needs indicated are understood as a state of the organism caused by a certain lack, which triggers internal imbalance of the organism and impedes the process of life and development. A need has a dynamic nature and its appearance can produce or start a process, which will direct an individual into undertaking certain actions in order to satisfy it. A need becomes a motive once it has been driven to a certain degree of intensity and thus prompts one to take action.

While drawing up motivational schemes, managers should be aware that, as regards employees, the work process touches not only the issue of remuneration, but also the opportunity to establish interpersonal relationships, improve self-esteem, be praised, develop and feel contentment and satisfaction. This is why the system of motivators should be selected according to the indi- vidual needs of the employees, showing them which behaviors and actions are promoted, and which ones should be avoided in the workplace.

\section{Empirical research analysis}

The question whether a company having introduced new management methods has met with reluctance on the part of its employees (SEE Diagram 1) has been answered by 101 respondents, $43 \%$ of whom (43 people surveyed) answered affirmatively. Any introduction of changes in organizations provokes anxiety within the working personnel. A company, which is unable to implement innovative management methods and communicate these changes to the outside world, no longer counts in the modern world economy.

Employees are afraid of changes as they are sure that they might lose something of special value to them. Another reason for the reluctance towards change is the difference in the employees' and the employer's analysis of the situation. Some employees oppose change as they fear they might have to acquire necessary new skills and improve their qualifications. Yet another reason might be leaving a team of friendly employees. 


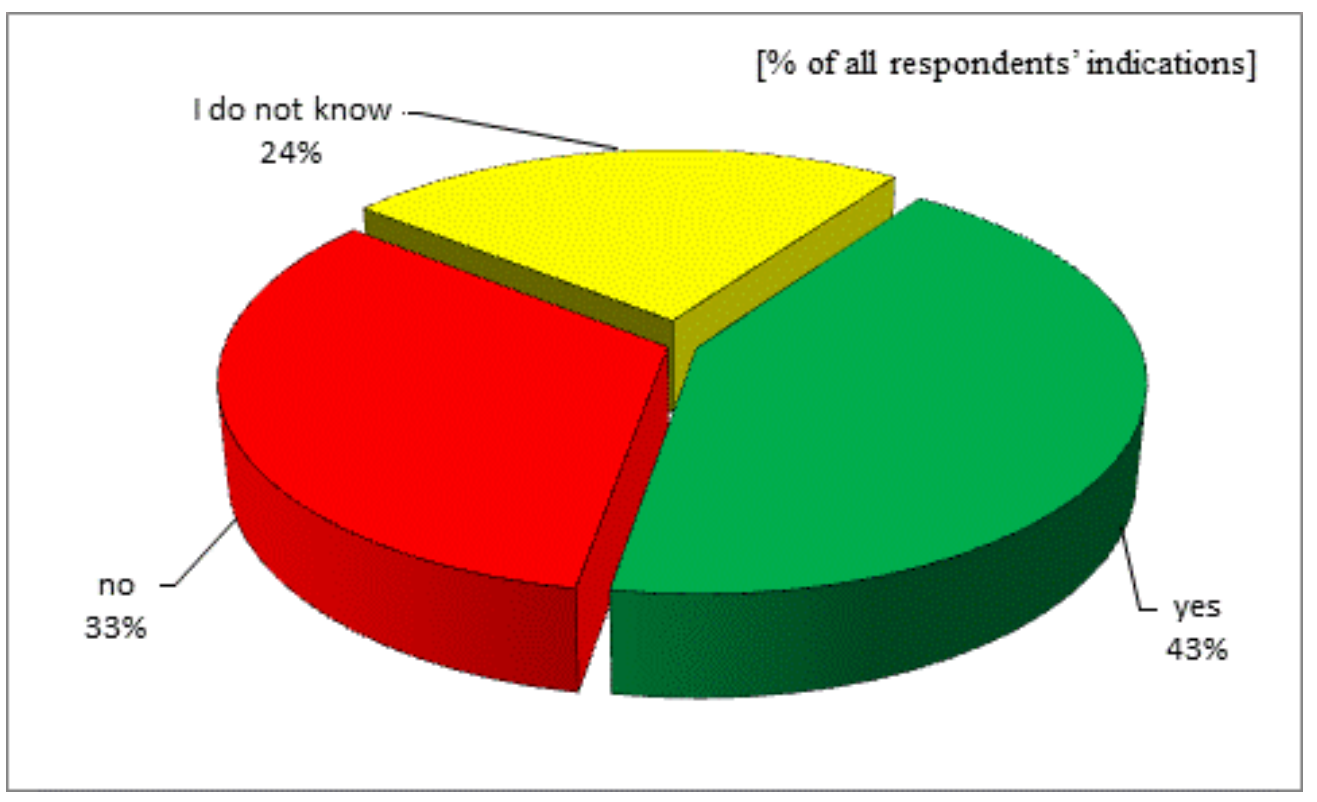

Diagram 1. The range of employees' opposition with regard to the implementation of new management methods in a company

(source: the authors' own study based on empirical research - the research included 216 respondents)

On the other hand, $33 \%$ of the respondents (33 people surveyed) answered negatively. This attitude indicates the respondents' understanding of new management methods, acceptance of what is consciously being introduced, organized and controlled by the company's managing personnel. It is necessary that employees accept the process of change as it is they who determine the success of the change project in an organization.

Twenty-four percent of the respondents answered that they did not know. This figure may indicate that the respondents in question are not interested in what is happening in the enterprise or that they do not identify with the company, because either they are employed on the basis of casual contracts or they do not plan to work in the company in the future.

Looking at Diagram 1, it has to be pointed out that the proper use of the opposition might bring more desirable effects than confrontation or not taking the case into consideration.

Opposition derives from the fear of the unknown or of failure, from lack of information, threat of losing the current status, lack of perceptible benefits, mistrust, negative reactions and threats, fear of losing informal relationships, as well as from a high level of anxiety and stress. Knowing the source of the opposition and anticipating it may open the door to using this situation effectively. The reluctance of employees stems from the fear that they will have to face various situations, which might be the consequence of the restructuring of the company or its production scheme. In companies where informal relationships are wrongly structured, managing staff and employees working in different functional departments hate one another. If the employees and the managing personnel are focused on their own interest rather than their company's aims, the opposition will be exceptionally large and impossible to overcome.

The data in Diagram 2 shows that as many as 56 respondents $(16 \%$ of the overall number of those surveyed) stated that some of the most important factors that motivate managerial staff and regular employees to implement new management methods in a company are financial means and the company's success. Fewer respondents (53 people, $15 \%$ of the total number of those surveyed), indicated that the motivating factor was career advancement. Some employees will be satisfied when their basic material needs are fulfilled, other will need more complex professional challenges. Improving competences guarantees success of employees on the labor market. A crucial motivator prompting workers to act in the best interest of the company is the opportunity for self-development [7, p. 213]. 


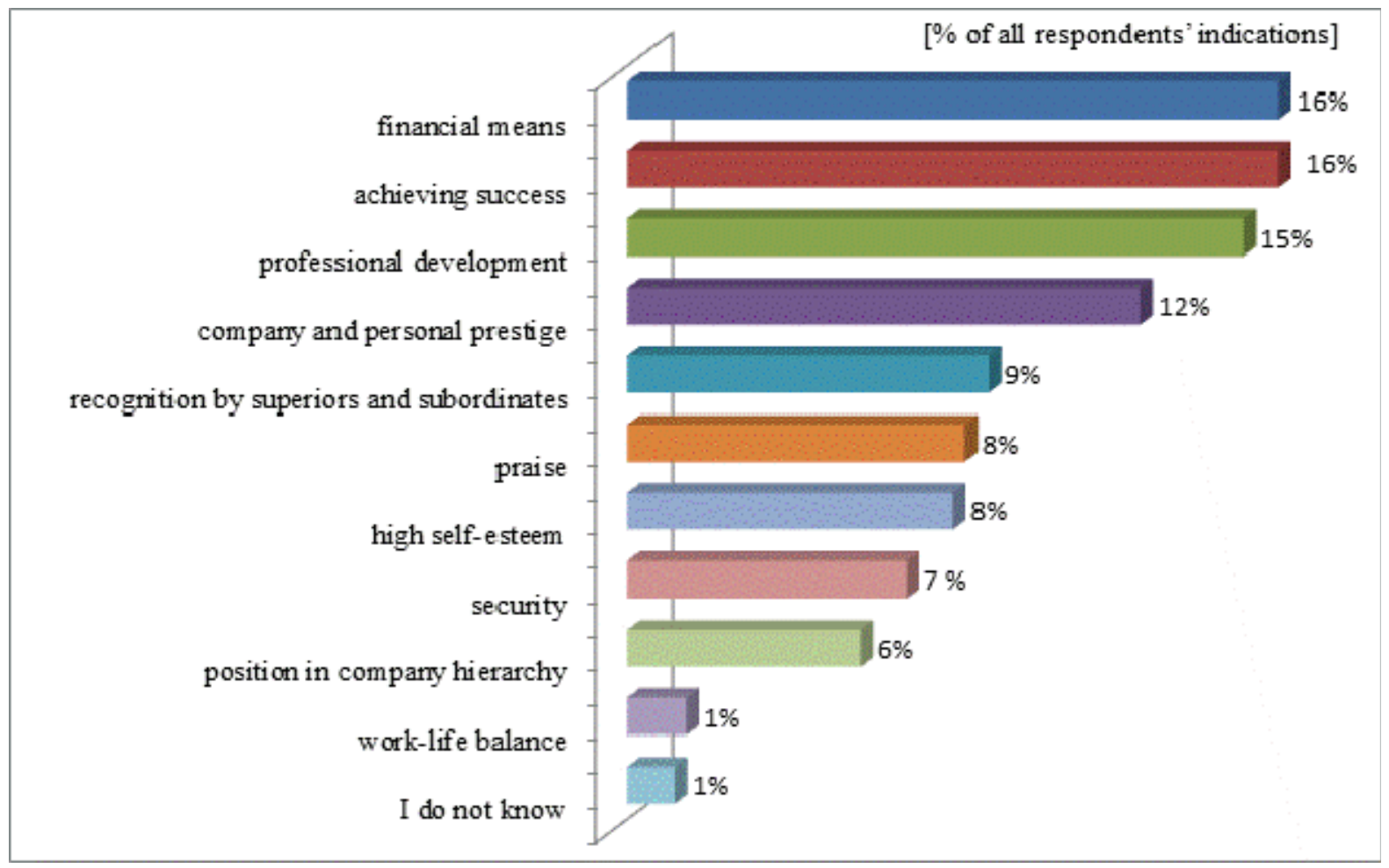

Diagram 2. Factors motivating managerial staff and employees to implement new management methods (source: the authors' own study based on empirical research - the research included 216 respondents)

As many as 44 respondents ( $12 \%$ of those surveyed) were in favor of enhancing the company's and their own prestige with the introduction of new management methods, whereas 29 respondents $(8 \%$ of those surveyed) declared that praise and high self-esteem are some of the most motivating factors. Praise ought to be concrete and clear, based on the effects observed and effort made by the employee. Managers should praise their employees before they complete their task, at different stages of the task completion, as this is how the employees strengthen their motivation and stamina. Respondents know that their smallest success contributes to the overall prosperity of the company. Twentyfour respondents ( $7 \%$ of those surveyed) stated that it was the feeling of job security, which was crucial. These days, it is necessary that enterprises, operating in uncertainty and chaos, ensure that this basic need is fulfilled.

Job security influences the quality of life of the workers and their development. It can be deduced that when job security is ensured, the employees are more motivated to do their work and are not afraid of changes in the company, which makes them work more effectively, and thus helps the company accomplish its objectives. Improving their position in the company structure was signaled as important by 20 respondents $(6 \%$ of those surveyed). The authors of the article are not surprised by this fact, as $96 \%$ of the respondents (70 people) declared to have completed higher education and as many as $39 \%$ of those surveyed hold the position of specialist or chief expert. This matter was subject of the research conducted by the authors on the issues of enhancing new concepts of managing business development. The presentation of the research scope is presented in another article [3, pp. 157-161]. The subject of the analysis is results of a survey conducted in the months of January and February 2013 in public and private enterprises of different sizes. Two hundred and sixteen questionnaires were distributed and completed. From the questionnaires returned, 101 were completed correctly. The survey was anonymous. It can be inferred from the data obtained that introducing new concepts of management in a company will contribute to employees' promotion to higher positions. As few as 5 respondents ( $1 \%$ of the total number) indicated work-life balance, whereas 4 respondents (1\%) claimed that they did not know the factors that motivated managerial staff as well as employees to implement new management methods. 


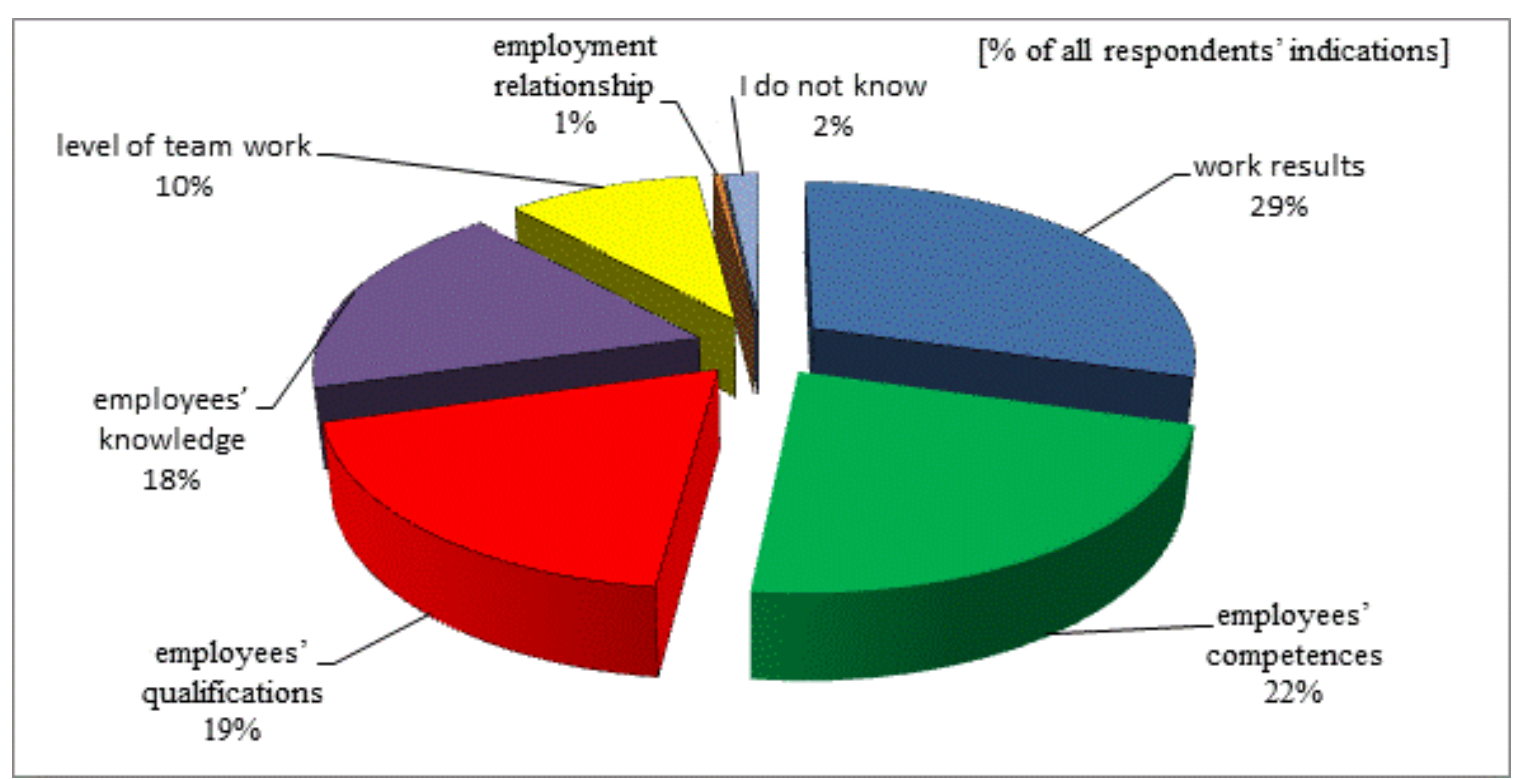

Diagram 3. Factors determining the introduction of new management methods in businesses (motivational function) (source: the authors' own study based on empirical research - the research included 216 respondents)

It can be understood that such a response was given by employees who have worked for the company for a relatively short period of time and do not yet know motivational factors occurring in businesses.

The visualization of the responses in Diagram 2 with regard to the factors that motivate employees and managerial staff to use new methods of management needs to be constantly assessed and revised. Introducing novelties implies the necessity to understand organizational behaviors towards them, which is why objectives and measures facilitating the process need to be determined carefully. In addition, a map of changes leading to the accomplishment of these objectives needs to be drawn up, and factors influencing the success of the approach chosen need to be identified. Introducing new management methods requires monitoring the map as well as making corrections if necessary, which will make the use of new management methods possible. The philosophy adopted ought to guarantee the following:

- a vision of survival, development and expansion in a turbulent environment,

- identification of employees and managerial staff with the company's vision, strategy and goals,

- predictable influence on the change process necessary for the completion of the vision.

Diagram 3 illustrates the responses to the question what the introduction of new management methods in businesses depends on as far as motivational factors are concerned.
The analysis of the data indicates that the most frequent determinant was work results $(29 \%, 71$ respondents). The second element was workers' competences $(22 \%$, 54 respondents). Competences of employees in businesses are understood as skills, experience as well as qualifications to take decisions on different positions, which is why this factor was indicated by such a big number of respondents, as it is a factor determining success for a given enterprise. Workers' competences are crucial for the completion of tasks on given positions and for proper functioning of the company. It is the employees' competences that are a measure of the economic, organizational and social performance of the business. Another determinant was employees' qualifications (19\%, 45 respondents). It is qualifications, which are subject knowledge, expert knowledge and expertise, which can be verified, measured and estimated. A qualified employee is one who has completed full-time education and has acquired knowledge and practice in a given area of study and who is legally authorized to work on a given post. This is why this indication is so important with regard to respondents who know their colleagues, as it is them, their competences and qualifications that the success of the company will depend on once new management methods are introduced. As many as 43 respondents (18\% of those surveyed) indicated knowledge of employees. "Knowledge workers" is a new category of workers in businesses. 
Their task is the productive use and exchange of knowledge. It is their responsibility to create and implement new ideas, thanks to which businesses will adapt their strategies to the quickly changing turbulent environment.

Their basic tasks are to search, exchange, link and make use of knowledge inside and outside the company. The level of teamwork was indicated by $10 \%$ of the respondents (23 people surveyed). Only 1 person indicated employment relationship (1\% of the surveyed), and 4 respondents ( $2 \%$ of the surveyed) said they did not know what the introduction of new methods in a business (motivational function) depended on.

The determinants of the introduction of new management methods in completing the motivational function (Diagram 3), in particular employees' qualifications, competences and knowledge as well as the results of their work, allow the chief staff to specify strategic areas of activity and focus in the fulfilling of business models for the company. Workers' knowledge and competences make it easier to establish a company policy and its game rules, which in consequence help to take important decisions. It is necessary here that one is aware of the importance of employees' knowledge and competences in the designing and redesigning of the architecture of managing a business, and that managerial staff and regular workers constantly need to improve their qualifications.

To answer which of the pay functions are used in the fulfillment of the motivational function in improving new management methods, $35 \%$ of the respondents indicated the motivational aspect (62 workers surveyed). The instrumental function of motivation has a psychological or economic aspect, or the two at a time. The first of these aspects is understood as a system of measures, which provoke emotional reactions and human attitudes [6, pp. 59-61]. The elements of the so-called psychological environment are the worker's duties, working conditions and position he/she takes in the society, thanks to the position held [9, p. 139]. The most important function of the economic aspect is using mechanisms that regulate the supply of salaries and bonuses. However, it has to be stressed that the economic aspect has a motivational function when it is based on rational management. In the case it expresses only 'obligation motivation', the influence will be purely directive.

As many as 28\% (49 respondents) indicated the income function. The income function means that the salary of employees is the main or quite often the only source of income for them and their families. Earning a salary is the deciding motive for undertaking work. This function underlines that income should be enough for the worker to regain his/her ability to work and to regenerate physical and mental powers by providing the necessary money to satisfy his/her elementary needs of life.

Only 33 respondents (19\% of those surveyed) indicated the cost function. The cost function is based on the company's costs related to paying employees salaries, which are the company's biggest cost. They are comprised of salaries and other employment-related costs, both financial and in kind as well as social insurance schemes [1, p. 19]. It needs to be underlined, however, that the level and variety of salaries determine the quality and structure of the personnel, their professional development and continuity of employment. Both the level and the diversity of salaries should be adapted to the system of values and expectations in a given country, community, professional group, as societies are very sensitive about salary issues. The social function was indicated by a slightly smaller number of respondents (as many as 26 , which is $15 \%$ of those surveyed).

Remuneration system in a business determines social relationships. It can be asserted that salaries have this function "because they are a sign of prestige, recognition and values of given employees and professional groups". The level and variety of salaries determine one's position in the society, influence interpersonal relationships and job satisfaction, as well as the occurrence of conflicts and strikes [8, p. 179]. Work that can be considered difficult and requiring high qualifications and skills as well as considerable dedication ought to be remunerated fairly and properly, otherwise the rank of some professions loses its importance.

Only 6 respondents (3\% of those surveyed) stated they did know the functions that were used in their company. 


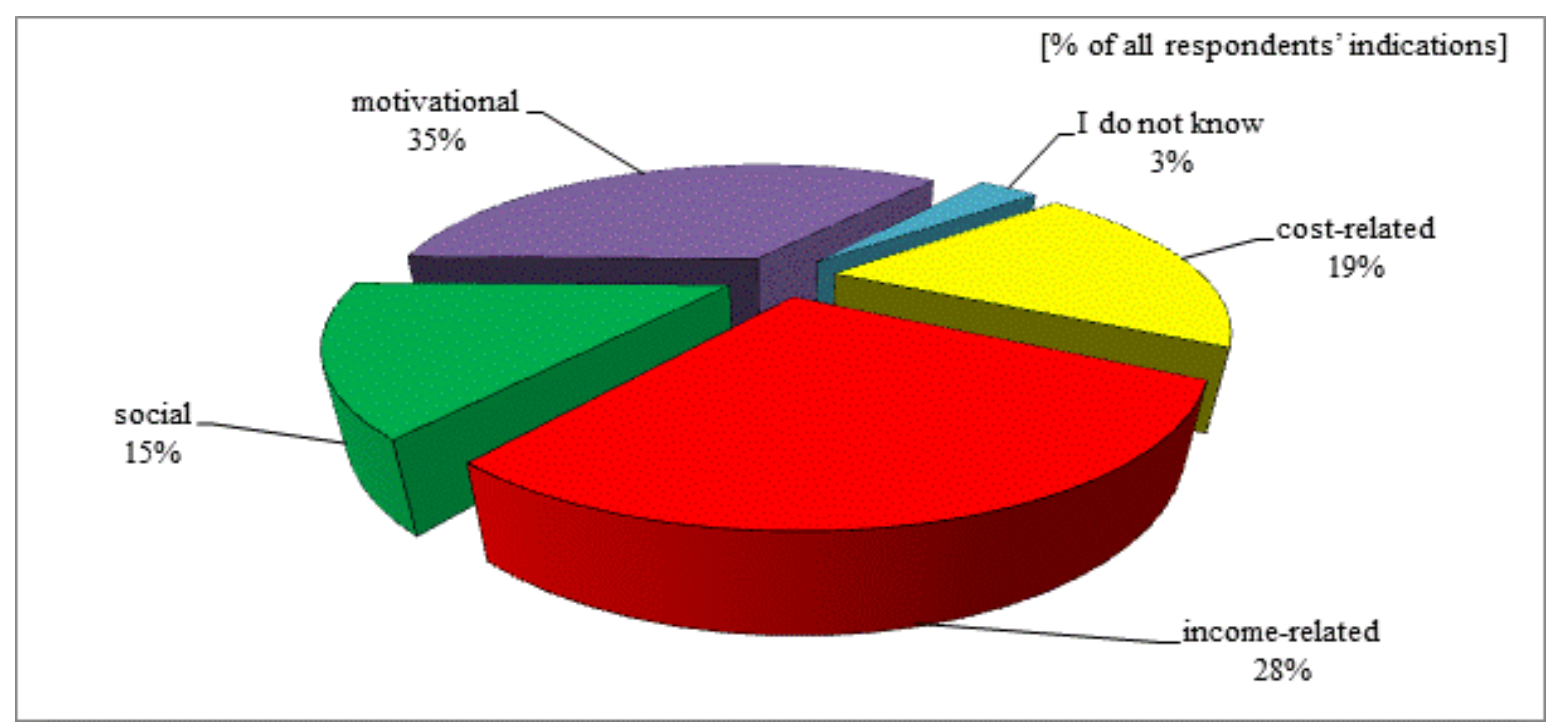

Diagram 4. The functions of salaries used in the fulfillment of the motivational function in enhancing new management methods

(source: the authors' own study based on empirical research - the research included 216 respondents)

Presented in Diagram 4, the functions of salaries used in the implementation of new management methods make it easier for employees and managerial staff to identify and accept their company's strategies in the times of risk and uncertainty. These functions also make for the integration and coordination of material and non-material resources, allowing the company to accomplish its goals, strategies, mission, and vision. The attractiveness of the salary function lies in the possibility of avoiding dysfunction and organizational chaos in the business. The risk this philosophy presents is the competition that occurs between the managerial staff and the employees for influence and the resources the company has to survive, develop, and expand. Uncertainty and the dynamic nature of the environment may trigger conflict and crisis in the functioning of the enterprise.

Diagram 5 illustrates the respondents' answers to the question which motivational tools are used in the company during the implementation of new management methods.

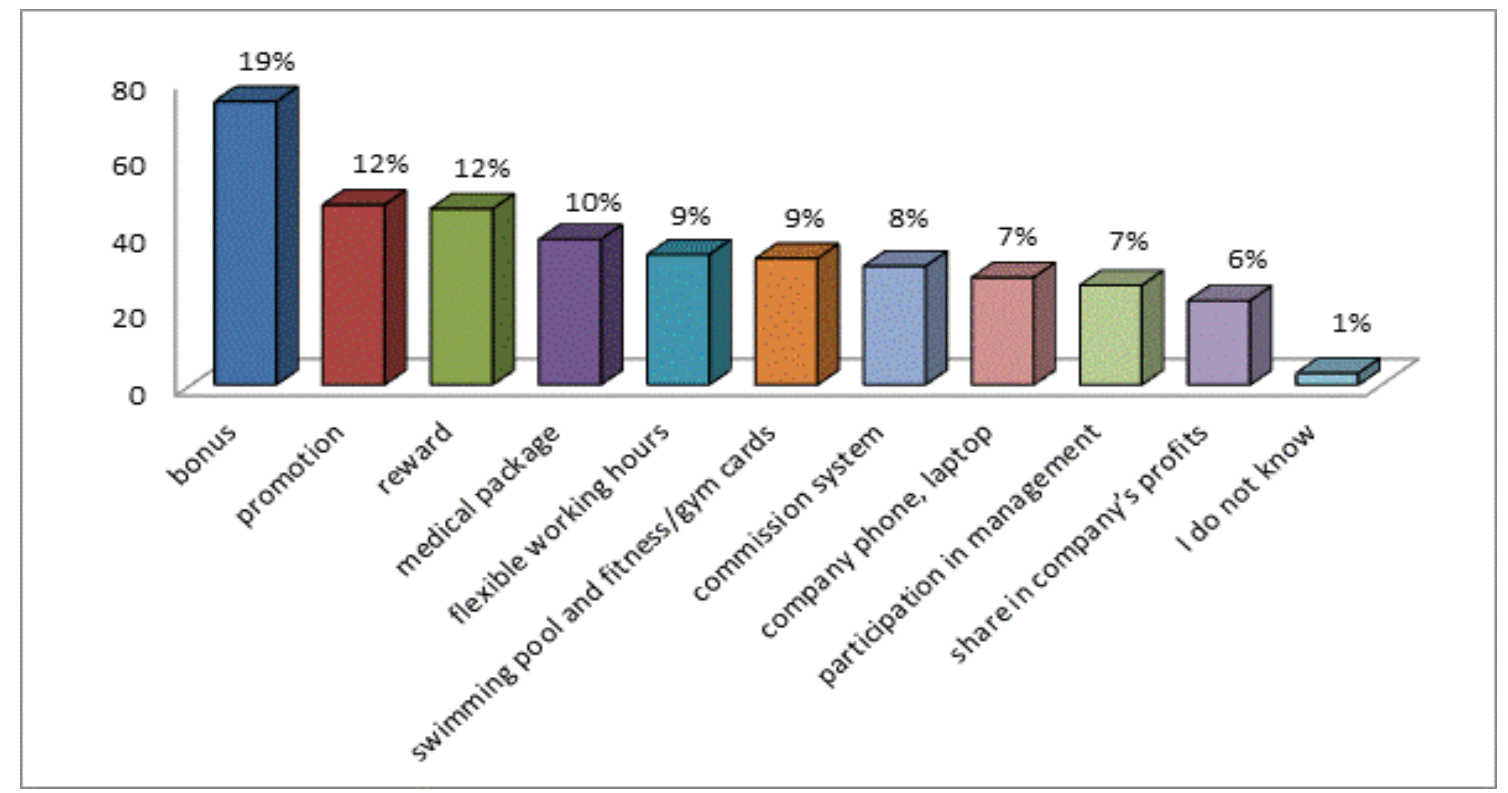

Diagram 5. Motivational tools used in companies during the introduction of new management methods (source: the authors' own study based on empirical research - the research included 216 respondents) 
The analysis of the data illustrates that the most frequently indicated motivational tool are bonuses, which were selected by $19 \%$ of all those surveyed ( 74 people), and rewards, which were selected by $12 \%$ of those surveyed (46 people). This shows that bonuses and rewards are of special motivational importance in the rewarding of employees. Relating them to work results encourages employees to ameliorate effects, which determines how often bonuses and rewards are given and what their level is. As bonuses are paid for the effects of work, they should be changed according to the changes in the effects of work in time.

One of the most important motivational tools indicated by $12 \%$ of the respondents was promotion (46 people surveyed). Promotion is one of the main functions that motivates employees to expand their knowledge, acquire new skills, try hard and be committed. Not only does it satisfy the need for recognition and high selfesteem, but it also allows employees to improve their standards of life and to gain access to higher values. Promotion carries enormous motivational force and it determines workers' behaviors.

Other motivational tools specified by respondents were medical package, flexible working hours and fitness/gym and swimming pool cards. They were indicated by $10 \%$ of the respondents (38 people), 9\% (34 people), and $9 \%$ (33 people) accordingly.

Fewer respondents ( $8 \%$ of those surveyed, 31 people) indicated commission and a slightly smaller number (7\% of those surveyed, 28 people) a company phone and laptop as well as participation in the management process. Having a share in the company's profit was indicated by $6 \%$ of the respondents ( 26 people).

Only $1 \%$ of the surveyed ( 3 people) said that they did not know what motivational tools were used in their company during the introduction of new management methods.

Judging by the respondents' indications in Diagram 5, it has to be asserted that businesses functioning in the times of risk and uncertainty make employees accept, in the spirit of ethics and cooperation, the prevailing rules through bonuses, promotion and flexible working hours. Such an approach implies trust, which is the philosophy adopted by employees, which expresses itself in their faith and commitment towards the employer. Promoting trust in the use of new management methods provokes quick reactions and encourages creativity and initiative, as well as quick exchange of information within the employees' and managerial staff's activity. As a consequence, the situation brings the business competitive advantage, which is based on flexibility and quick reaction.

\section{Conclusions}

The article presents analysis of the respondents' indications pertaining to new management concepts in the fulfillment of motivational function in business practices. Based on the empirical research, the following conclusions can be drawn:

1) One of the biggest problems managers face today is the opposition of employees to change. It can lead to the worsening of work results, conflicts, intentional slowing down the pace of work and thinking that the changes will not bring expected results, but dismissal. This is why managerial staff should inform employees about intended restructuring. Appropriate flow of information will convince employees that changes are necessary and will discourage them from opposing them. Participation of employees in deciding on the direction the restructuring takes will inspire them to work more effectively and efficiently, and thus will contribute to the increased productivity of the business.

2) Participation of employees in management understood as tactics of change implies that managers will allow employees who oppose or might oppose change to decide on the direction the designing and implementing of change will take in the company.

3) Financial means are a very effective tool, which is used to motivate employees. Managers should understand the power of rewards. Intuitively, employers resort to rewards to influence behavior of employees, but their effort does not always bring desired results as they use improper strategies for rewarding their subordinates. In order for pay to motivate employees to work well, develop professionally, be promoted and act as expected by the employer, the following conditions need to be met [1, page 22]:

- the remuneration system needs to be known by all employees and taken as logical, fair and used consistently by the employer,

- the remuneration should be equitable and based on the results obtained by the employees for the employer, 
- part of the remuneration should be performance-related and based on the attitudes and behaviors of employees,

- the time span between executing a task and being rewarded for it should not be too long to erase the connection between work and pay,

- the influence of employees on the work effects that are rewarded should be made visible.

4) If managers want to have influence on their subordinates' behaviors, they need to determine what consequences of the behaviors have desirable value to them and they need to be able to manipulate the consequences of those behaviors.

\section{$4 \quad$ References}

[1] Borkowska St. - Strategie wynagrodzeń (Remuneration strategies). Oficyna Ekonomiczna Dom Wydawniczy ABC, Cracow 2001.

[2] Januszek H., Sikora J. - Socjologia pracy (The sociology of work). Akademia Ekonomiczna w Poznaniu, Poznań 1998.

[3] Kułakowska A., Piątkowski Z., Mazur K., Pawłowski M. - Nowoczesne metody zarzadzania $w$ praktyce przedsiębiorstw (New management methods in business practices). Postępy Techniki Przetwórstwa Spożywczego (Technological Advances in Food Processing), Warsaw 2013, No. 2.

[4] Kułakowska A., Piątkowski Z., Żebrowski W. Barriers for Empowerment in Organisations on the Basis of Survey [in] Foundations of Management, Vol. 2 No. 1, 2010.

[5] Pawłowski M., Piątkowski Z., Żebrowski W. Management Efficiency [in] Foundations of Management, Vol. 1, No. 1, 2009.

[6] Reykowski J. - Teoria motywacji a zarzadzanie (Motivation theory and management). Książka i Wiedza, Warsaw 1979.

[7] Szaban J. - Miękkie zarzadzanie. Ze wspótczesnych problemów zarzqdzania ludźmi (Soft management. Current issues of human resources management). Wydawnictwo Wyższej Szkoły Przedsiębiorczości i Zarządzania im. Leona Koźmińskiego, Warsaw 2003.

[8] Smyk E. - Systemy wynagradzania (Remunaration systems). Oficyna Wydawnicza Szkoły Głównej Handlowej, Warsaw 1998.

[9] Stabryła A. - Zarzqdzanie rozwojem firmy (Managing business development). Akademia Ekonomiczna w Krakowie, Wydawnictwo Uczelniane, Cracow 1996. 